\title{
Relationship between Crude oil price and Rupee, Dollar Exchange Rate: An Analysis of Preliminary Evidence
}

\author{
Dr.A.Hidhayathulla ${ }^{1} \&$ Mahammad Rafee.B ${ }^{2}$ \\ ${ }^{1}$ Associate Professor of Economics, Jamal Mohamed College, Tiruchirappalli, India \\ ${ }^{2}$ Research Scholar (Ph.D MANF JRF), Jamal Mohamed College, Tiruchirappalli, India
}

\begin{abstract}
The objective of this paper is to examine the effects of oil price on exchange rate of Indian rupee against US dollar using time series data from 1972-73 to 2012-13. Multiple linear regression models are used to analyse the data. The model result suggests that the import of crude oil continues to rise up when the crude oil future price increases. The oil imports thus became a substantial source of demand for dollar in India's foreign exchange market. This strong demand contributes to strengthen the dollar against Indian rupee, among the other factors. This finding will contribute to Indian government in making policy to control the petrol price to avoid rupee depreciation against US dollar.
\end{abstract}

Key Words: Oil price, Exchange rate, Imports of crude oil, Multiple linear regression.

\section{Introduction}

India is the 7th largest country with the land mass of 3.29 million square Kilo meter and second largest in population of over 1.2 billion. It accounts for 17.2 percent of the world population. The country has to produce about one trillion worth of GDP to fulfill the needs of its huge population. In order to produce this one trillion dollar worth of output, India needs 2.5 million barrels of oil per day. This is 4.4 percent of total world demand for oil. The growth rate of demand for oil is around 6.8 percent (FICCI Report 2012). This ever growing demand exerts profound influence on the growth and inflation levels in India. International oil price is likely to affect the domestic prices. However in India's case the sharp increase in international oil prices has not been fully transmitted in to the domestic prices. The administrated price mechanism had shielded the country from the impact of oil shocks. The government of India has given up the administrated price mechanism in oil sector and linked the domestic oil prices with international oil prices. Oil price as external factor certainly affects the Indian economy, especially the Indian currency where US dollar is the acceptable currency in International market, thus it became the problem of research investigation. The impact has been assumed with regard to exchange rate of rupee to dollar alone. So the impact assessment would be partial, because oil prices can penetrate into other macro economic variables and all the sectors of the economy. The public sector oil companies and consumers have shared the burden of oil price increase in the form of increased prices (inflation). Public sector companies are backed by budget support of the government. Recently it has deregulated all petroleum products except LPG Cylinder and Kerosene (subsidized by Government of India) and ultimate burden is shifted to people in the form of taxes. Since Energy is the driver of economic growth and energy from the oil is the largest source of energy supply, payment to oil eats up substantial portion of foreign exchange of oil consuming countries. India's oil import bill is around 30 percent of her total imports. India's crude oil import bill has jumped by 9.5 percent to $\square 3,47,432$ crores in the first five months of 2013, India depends on imports to meet 80 percent of the needs, and imported 81.499 (Million Tonnes) crude oil during the April-August period, up by 8.82 percent from 74.892 Million Tonnes in the same period a year ago according to Petroleum Ministry of India.(Business Line September 23, 2013) Many counties like USA, Malaysia are able to keep stable retail price of oil while many developing countries like India are having volatile retail price of oil. Of the various sensitive issues that can make or break a government in India, petrol pricing is one. As on 10 Dec 2012, petrol price in India is $\square 72.3$ (Average price of Metros). If we take Delhi as a base, it has fluctuated 30 times over the past 4 years causing an increase by 47percent. On May 23, 2012 petrol saw its steepest hike everby $\square 7.54$ leading to nationwide protests by the opposition and the general public. Petrol prices account for 1.09percent weightage of overall WPI (Wholesale Price Index). This implies that an 11.5percent increase (due to the hike of $\square 7.54$ ) increases the inflation by $13-15$ basis points. 


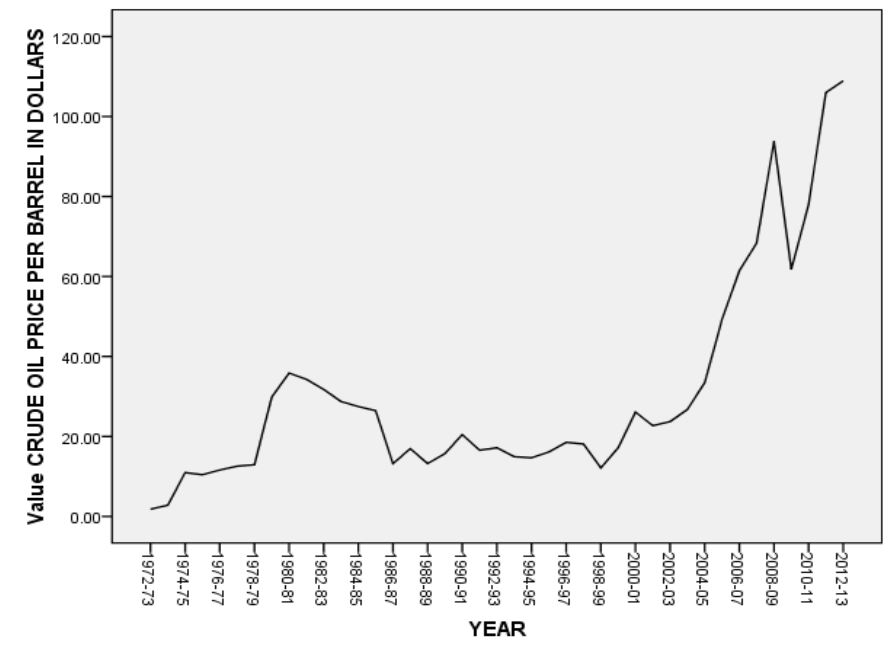

Figure.1.Crude oil price per barrel in US dollars (Futures price WTI)

Inflation, as we know, reduces the purchasing power of the Rupee and effectively makes people poorer. In a country where 77 per cent of the population spend 60-80 per cent of their meager $\square 600$ monthly income on food (according to the Report of the National Commission for Enterprises in the Unorganized Sector), the price of petrol is out of reach of the poorer majority who cannot afford the costs of private transport. Therefore, the study that addresses the nuances of consequences of oil price hike and its relationship with exchange rate of rupee against US dollar assumes significance.

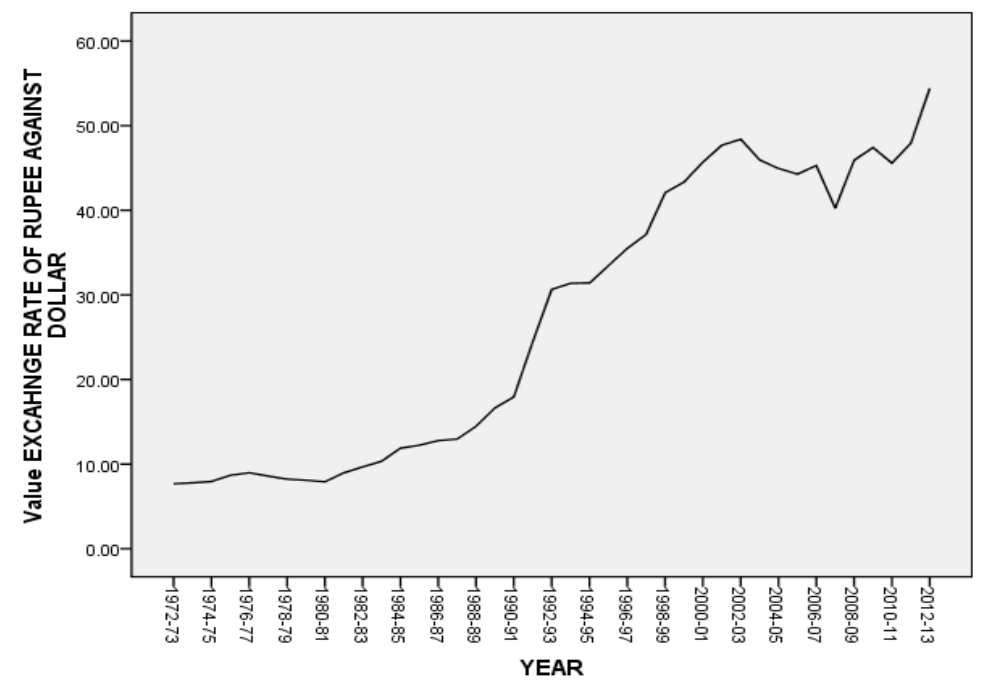

Figure.2.Exchange rate of Rupee against US dollar

The rest of this paper is divided into three sections. The second section comprises of review of literature on crude prices and exchange rate. The third section is devoted to data and methodology and empirical results. The fourth section offers concluding comments.

\section{An Overview Of Literature On Oil Price And Exchange Rate Relationship:-}

Ibrahim Tuhran and et.al (2012) examined the dynamic relationship between oil prices and exchange rate of selected emerging economies. It contributes to the literature in at least three points, first contrary to the general use of developed economies, the author opted emerging markets to study the relationship between oil prices and exchange rates. Second, un-parallel to the literature using monetary models to explore the exchange rates with low frequency data, oil is taken as alternative asset class and use daily oil price data to investigate the dynamics of exchange rate of an emerging market. Third, this paper shows how this relation has changed by comparing the relationship before and after the financial crisis. The study used exchange rates of 13 emerging countries during 2003-10.The study used 5 day week daily time series data for the period 01-03-2003 to 06-02-2010. Dated Brent Oil price and the US dollar and the US dollar price of JPMorgan emerging market bond index plus (EMBI+) countries exchange rates are sourced from Bloomberg. The study employed three different unit root tests for each returns and each time frame separately. Although the unit root tests sometimes yield contradictory results, the results indicate that in all time frames all exchange rates returns and oil returns are stationary in 
levels. The results show that oil price movements get an increased importance after the financial crisis, as oil prices rise there is an apparent depreciation of the local currency against the US dollar and the co-movements has increased during the study period. There are number of reasons why this co-movement is getting stronger. One reason is that emerging economies have recovered more quickly than developed countries from the crisis Increasing oil prices create a positive sentiment to emerging economies as they are expected to grow faster than the developed economies.

Mohammad Shaidan Shaari and et.al (2012) studied the effects of oil price shock on inflation in Malaysia using monthly data from 2005 to 2011.The study used world crude oil price index(in Malaysian Ringgit, RM) consumer price index, CPI (based index value of 100 in year 2005) and exchange rate (RM per \$ 1 US dollar). VAR-VECM and Granger causality model were employed to analyze the data. The empirical findings show, that the co- integration between all variables exists at 5percent significance level in the long run. But in the short run only crude price affected the inflation. From Granger causality test, it is found that inflation does not granger cause the exchange rate but it does granger cause the oil price. The oil price does granger cause the inflation but it does not granger cause the exchange rate. The exchange rate does not granger cause both of the variables (inflation and oil prices). So, the change in crude price changes the inflation. This finding will contribute to Malaysian government in making policy to control the petrol price to combat inflation.

Ademola Ojebiyi and David Olugbenga Wilson (2011) analysed exchange rate volatility through an analysis of the relationship between the Nigerian Naira, oil prices and US dollar. The model results show that there is a weak/negative relationship between exchange rate and oil price as there are other factors that bring about changes in oil price other than the exchange rate. The activities of cartel pricing policy and oil speculators too have come to greatly affect the price of crude oil. The results convey that there are other factors that affect the change in oil price apart from the exchange rate. Crude oil price change is usually very sensitive to events around the world and tensions in the oil producing nations. OPEC too affects the price of crude oil by increasing or decreasing the allocations to be sold by the countries.

Syed Abul Basher and et.al (2010) investigated the dynamic relationship between real oil prices, exchange rate index for major currencies, emerging market stock prices, interest rates, global real economic activity and oil supply. The results of this paper support to some extent that oil prices respond to movements in exchange rates. Further, the result reported in the paper offered some support for higher oil prices affecting exchange rates in the short run. In particular positive oil shock leads to immediate drop in the trade weighted exchange rate. On the other hand oil prices respond negatively to an unexpected increase in oil supply and oil prices respond positively to an unexpected increase in demand. These results are consistent with the prediction from a demand and supply model for the oil market. Oil prices respond positively to positive shock in emerging stock markets, while respond negatively to the positive shock. These results are important in establishing that in addition to global supply and demand conditions for oil, oil prices also respond to emerging economy equity markets and global capital markets.

Mukhriz Izraf Azman Aziz (2009) estimated the long run effect of oil price and real interest rate differential on real exchange rate for a monthly panel of 8 countries from 1980 to 2008. Data are sourced from International Financial Statistics (IFS) published by IMF. Real exchange rate is constructed by using domestic price level and price level in a foreign country. Real exchange rate is equal to nominal exchange rate (foreign price level/domestic price level). Real oil prices are defined as the price of Dubai crude oil expressed in US dollar. The panel tests are based on within dimension approach (that is panel co-integration statistic) like v-statistic, panel p-statistic, panel Ipp-statistic and panel ADF-statistic. The paper has found evidence of non-stationarity for the three series for all groups of countries. For real oil price and real exchange rate, the series contain unit root as all panel unit root tests fail to reject the null hypothesis of unit root at 1 percent level of significance. For real interest rate differential, it appears to be weekly non-stationary especially for oil exporting countries and panel of eight countries as the null hypothesis of unit root can only be rejected at 10 percent significance level by most unit root tests. The paper has shown evidence of long-term relation between the three series and of causality running from real oil price to the real exchange rate.

\section{Data And Methodology:-}

The data on oil prices were downloaded from knomea.com. Data relating to exchange rate and imports of Crude oil were downloaded from RBI Publication (Hand book of Indian Statistics 2012-13). The study employs an empirical analysis and only focuses on three chosen variables. The variables that we use are the world crude oil prices in US Dollars, imports of crude oil in million tonnes by India and exchange rate of rupee per \$1 US Dollar. Time series data from 1972-73 to 2012-13 are used for all the variables. Two separate model equations are constructed to examine the relationships. The relationship between import of crude oil and future price of crude oil is examined using the following equation.

$$
\mathrm{OI}_{\mathrm{t}}=\beta_{0}+\beta_{1} \mathrm{OP}_{\mathrm{t}}+\mathrm{U} \ldots \ldots \ldots \ldots \text { (1) }
$$


Where

$\mathrm{OP}_{\mathrm{t}}=$ Crude oil prices (West Texas Intermediate Future price per barrel) for the time period $\mathrm{t}$

$\mathrm{OI}_{\mathrm{t}}=$ Oil Imports (in million tonnes) for the time period $\mathrm{t}$

In order to analyse the relationship between exchange rate of Indian rupee Vs dollar and import of crude oil the following model is constructed.

$$
\square \$ \mathrm{X} \text { rate }_{\mathrm{t}}=\beta_{0}+\beta_{1} \mathrm{OI}_{\mathrm{t}}+\mathrm{U}
$$

$\square \$ X$ rate $_{\mathrm{t}}=$ Exchange rate of Indian Rupee against Us Dollar for time period $\mathrm{t}$

$\mathrm{OI}_{\mathrm{t}}=$ Oil Imports (in million tonnes) for the time period $\mathrm{t}$

The oil marketing companies (OMC's) purchase crude oil by buying the futures contract and taking delivery. Therefore the futures price is chosen as explanatory variable. However it doesn't directly affect the exchange rate of India. The exchange rate is influenced by crude oil imports. Therefore two separate model equations are used to analyse the relationship.

\subsection{EMPIRICAL RESULTS: -}

Investment decisions of oil derivative investors determine the futures prices of oil. They speculate price changes and take investment decisions. The financial market decisions drive the real market prices. The model result suggests that the import of crude oil continues to rise up when the crude oil future price increases. The oil imports thus became a substantial source of demand for dollar in India's foreign exchange market. This strong demand contributes to strengthen the dollar against Indian rupee, among the other factors. The estimated model equation shows that along with one dollar increase in futures price of crude oil the imports of crude oil of India raises up by 1.703 Million tonnes. The Second equation shows that every one million tonne of crude oil import strengthens US dollar by 0.266 against Indian rupee.

Table No.1

\begin{tabular}{|l|l|l|l|l|l|l|l|l|}
\hline & $\begin{array}{l}\text { Dependent } \\
\text { variable }\end{array}$ & $\begin{array}{l}\text { Independent } \\
\text { variable }\end{array}$ & $\mathrm{R}^{2}$ & $\begin{array}{l}\beta_{0} \\
\text { Constant }\end{array}$ & $\begin{array}{l}\beta_{1} \\
\text { Value }\end{array}$ & Significance & $\mathrm{F}$ \\
\hline I & Oil imports (OI) & Oil prices (OP) & 0.773 & 0.810 & 1.703 & 0.000 & 133.033 & 11.534 \\
\hline II & $\begin{array}{l}\text { Exchange } \\
\text { rate( } \square \$ \text { X rate) }\end{array}$ & Oil imports (OI) & 0.681 & 13.021 & 0.266 & 0.000 & 83.245 & 9.124 \\
\hline
\end{tabular}

\section{Conclusion:-}

This paper examined the effects of oil price on exchange rate of Indian rupee against dollar using time series data from 1972-73 to 2012-13. Oil price and imports are rising continuously. This pushes up the demand for dollar which strengthens the dollar against rupee and Indian rupee is continuously depreciating. This erodes purchasing power of Indian currency in the international market. The domestic oil supply augmentation and control over oil demand seems to be viable policy option to overcome exchange rate depreciation and its consequences.

\section{References:}

[1]. Ibrahim Tuhran and et.al (2012) "oil prices and emerging market exchange rates", Central Bank of republic of Turkey, Middle East Technical University-MPRA Paper No: 36477, Feb 2012.

[2]. Mohd.Shaidan shaari and et.al (2012) "the effects of oil price shocks and exchange rate volatility on inflation: Evidence from Malaysia". International Business Research: Vol. 5, No. 9; 2012.

[3]. Ademola ojebiyi and David olugbenga Wilson (2011) "Exchange rate volatility: an analysis of the relationship between the Nigerian Naira, oil prices and US dollar- Master of International Management, Gotland University, Spring semester 2011.

[4]. Syed Abul Basher and et.al (2010) "oil prices, exchange rates and emerging stock markets".MRPA Paper No:30140, April 2011.

[5]. Mukhriz Izraf azman Aziz (2009) "oil price and exchange rate: a comparative between net oil exporting and net oil importing countries". Lancaster University, August 2009.

\section{Online Sources:}

http://www.wtrg.com/prices.htm

http://www.eia.gov/dnav/pet/pet_pri_spt_s1_d.htm

http://www.mypetrolprice.com

http://www.hindustantimes.com/business-news/Markets/Nation-wide-protests-on-petrol- price-hike-may-delay-diesel-reform/Article1860727.aspx.

http://www.financialexpress.com/news/the-logic-of-tradeparity-pricing/92053/0

http://www.ongcindia.com/Financial_Highlights/ONGC_OVL_MRPL_FY12_Result.pdf

http://articles.economictimes.indiatimes.com/2012-11-09/news/34994182_1_subsidy-burden-sudhir-vasudeva-oil-production

http://businesstoday.intoday.in/story/indian-companies-ril-ioc-in-top-100-of-fortune-500-list/1/186125.html 